\title{
Effects of selenoprotein S on oxidative injury in human endothelial cells
}

\author{
Yin Zhao ${ }^{1+}$, Hua Li ${ }^{2 \dagger}$, Li-li Men ${ }^{1}$, Rong-chong Huang ${ }^{1}$, Hai-cheng Zhou', Qian Xing ${ }^{1}$, Jun-jie Yao ${ }^{1}$, Chun-hong Shi ${ }^{1}$
} and Jian-ling Du ${ }^{1 *}$

\begin{abstract}
Background: Selenoprotein S (SelS) is an important endoplasmic reticulum and plasma membrane-located selenoprotein implicated in inflammatory responses and insulin resistance. However, the effects of SelS on endothelial cells (ECs) have not been reported. In the present study, the role of SelS in oxidative stress and the underlying mechanism were investigated in human ECs.

Methods: A SelS over-expression plasmid (pc-SelS) and a SelS-siRNA plasmid were transfected into human umbilical vein endothelial cells (American Type Culture Collection, USA). The cells were divided into four groups: control, SelS over-expression (transfected with pc-SelS), vector control, and SelS knockdown (transfected with siRNA-SelS). After treating the cells with $\mathrm{H}_{2} \mathrm{O}_{2}$, the effects of oxidative stress and the expression of caveolin-1 (Cav-1) and protein kinase $\mathrm{Ca}(\mathrm{PKCa})$ were investigated.

Results: Following treatment with $\mathrm{H}_{2} \mathrm{O}_{2}$, over-expression of SelS significantly increased cell viability and superoxide dismutase (SOD) activity, and decreased malondialdehyde (MDA) production and Cav-1 gene and protein expression. However, no effects on PKCa were observed. In contrast, knockdown of SelS significantly decreased cell viability, SOD activity, and PKCa gene and protein expression, and increased MDA production and Cav-1 gene and protein expression.
\end{abstract}

Conclusions: SelS protects ECs from oxidative stress by inhibiting the expression of Cav-1 and PKCa.

Keywords: Endothelial cell dysfunction, Oxidation, Selenoprotein S, Caveolin-1, Protein kinase Ca

\section{Background}

Atherosclerosis (AS) is a major life-threatening disease in modern society. However, the exact mechanism of AS development is not completely understood and effective therapies are still required [1]. It has been shown that endothelial cell dysfunction (ECD) not only triggers but also promotes the development of AS [2]. Moreover, oxidative stress is considered to be a primary event in the pathogenesis of ECD and AS. Therefore, many resources have been directed towards research into endothelial protection strategies against oxidative injury in recent years.

Many selenoproteins, including glutathione peroxidase 1 (GPx1), thioredoxin reductases (TRs), selenoprotein W

\footnotetext{
*Correspondence: dujianling63@163.com

${ }^{\dagger}$ Equal contributors

'Department of Endocrinology, The First Affiliated Hospital of Dalian Medical University, Dalian 116011, Liaoning, China

Full list of author information is available at the end of the article
}

(SelW) and selenoprotein P (SelP), participate in intracellular redox homeostasis and play antioxidative roles [3-6]. Tanis, the homolog of Selenoprotein S (SelS), was first characterized as a transmembrane protein in the liver of the Israeli sand rat, Psammomys obesus [7]. SelS expression was later found in a pancreatic $\beta$ cell line, endothelial cells (ECs), human adipose tissue and skeletal muscle tissue [8-10]. The expression of SelS is related to inflammation and insulin resistance (IR) in liver and adipose tissue $[8,11,12]$. High expression of SelS protected the pancreatic $\beta$ cell line, Min6, from oxidative damage induced by $\mathrm{H}_{2} \mathrm{O}_{2}$ [8]. Reduced expression of SelS led to more severe inflammation in a lipopolysaccharide (LPS)-injured hepatic cancer cell line [12], suggesting that SelS may provide a link between IR, inflammation and oxidative stress pathways through its role as an antioxidant. Although the effect of SelS on oxidative stress in ECs has not yet been reported, it is well

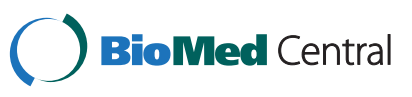


known that oxidative stress is the common key factor of IR, AS and ECD. Therefore, SelS/Tanis is likely to be an important mechanistic target for the prevention and therapy of AS-ECD.

Caveolae, a special type of lipid raft, are highly expressed in endothelial membranes. Caveolin-1 (Cav-1), the principal marker protein of caveolae, participates in the pathologic processes of inflammation and IR $[13,14]$, leading to ECD. The special scaffold structure of Cav-1 modulates the activity of protein kinase $\mathrm{C}$ (PKC) during oxidative stress, while PKC regulates gap junctions through Cav-1-containing caveolae. PKC is recruited into Cav-1-containing lipid rafts in the cell membrane from the cytoplasm to induce the redistribution of PKC and Cav-1 in lipid rafts, suggesting a possible interaction between Cav-1 and PKC [15]. SelS has four potential phosphorylation sites for PKC. SelS is also similar to Cav-1 in that it is a membrane protein highly expressed in ECs. To our knowledge, the interaction between SelS and Cav-1 in the oxidative stress pathway of ECs has not been reported previously. In this study, we investigated whether SelS participates in the oxidative stress pathway in ECs using a gain/loss of SelS function strategy combined with analysis of the expression levels of Cav-1 and PKC $\alpha$ following treatment with $\mathrm{H}_{2} \mathrm{O}_{2}$.

\section{Methods}

Construction of the SelS over-expression plasmid, pc-SelS A SelS gene fragment (579 bp) was amplified from human adipose tissue by reverse-transcription polymerase chain reaction (RT-PCR). Specific primers were designed according to the nucleotide sequence of human SelS [GeneBank: NM-018445]. The sense primer sequence was 5'-CCGCTCGAGATGGAACGCCAAGAGGAGTC TCTG-3', and the antisense primer sequence was $5^{\prime}$ CCGGAATTCGCCTCATCCGCCAGATGACGGGCC-3'. Restriction enzyme sites were introduced into the sense primer (XhoI at the $5^{\prime}$ end) and antisense primer (EcoRI at the $3^{\prime}$ end) to enable subcloning of the amplified fragment. The PCR product was cloned into the pMD18-T Simple Vector and then digested with XhoI and EcoRI. The digested SelS DNA fragment was purified and subcloned into the pcDNA3.1 eukaryotic expression vector to generate the pcDNA3.1-SelS recombinant plasmid (pc-SelS). After confirming the DNA sequence, pc-SelS was transiently transfected into human umbilical vein endothelial cells (HUVECs) via liposomes.

Construction of the SelS low expression plasmid, siRNA-SelS Three interfering target sequences and one negative control (HK) were designed according to the human SelS gene sequence [GeneBank: NM-018445] using online software provided by Wuhan Jing Contest Company and synthesized into double-strand DNA templates. The sequences were as follows: SelS1, 5'-GCAUCCUUCU CUACGUGUUCAAGACGCACGUAGAGAAGGAUG CUU-3'; SelS2, 5' -CUGUGGAACCUGAUGUUUUCA AGACGAACAUCAGGUUCCCAAGUU-3'; SelS3, 5' AGCAGCUGCUCGACUGAUUCAAGACGUCAGUC GAGCAGCUGCUUU-3'; HK, 5'-GACUUCAUAAGGC GCAUUUCAAGACGAUGCGCCUUAUGAAGUCUU-3'. After cloning into the pcDNA3.1 eukaryotic expression vector and sequencing, the correct clones were transformed into E. coli DH5 $\alpha$. Kanamycin-resistant clones were expanded and three interfering plasmids for siRNASelS were sequenced before transfection into HUVECs.

The conditions for plasmid transfection were initially optimized. Briefly, HUVECs were seeded in six-well plates and cultured in minimum essential medium supplemented with 10\% fetal bovine serum (Invitrogen Corp, USA) for 24 hours. When the cells had reached approximately 90\% confluence, transfection was performed in serum-free medium using Lipofectamine 2000 (Invitrogen Corp), with different ratios of plasmid to Lipofectamine. According to the transfection efficiency under a fluorescence microscope, a 1:1.5 ratio of plasmid $(\mu \mathrm{g})$ to liposome $(\mu \mathrm{l})$ was selected for the experiments.

The interfering effects of three siRNA-SelS plasmids on gene expression were investigated. Briefly, 4 hours after transfection, cells were transferred into normal medium for 24 hours before being harvested. Gene expression was analyzed by RT-PCR. Finally, one siRNASelS plasmid was chosen for the following experiments according to its interfering effects (Figure 1).

\section{Expression of pc-SelS and siRNA-SelS in HUVECs}

HUVECs were divided into the following four groups: normal control group, vector control group, pc-SelS group (SelS over-expression group transfected with pc-SelS), and siRNA-SelS group (SelS low expression group transfected with siRNA-SelS). The cells were harvested 24 hours after transfection. Gene expression was analyzed using real-time PCR and protein expression was analyzed by western blotting with a rabbit anti-human SelS polyclonal antibody (prepared by Wuhan Jing Contest Company, China).

\section{Effects of SelS on $\mathrm{H}_{2} \mathrm{O}_{2}$-injured HUVECS Analysis of cell viability using the MTT assay}

HUVECs were divided into the four groups described above (normal control group, vector control group, pcSelS group, siRNA-SelS group). Twenty-four hours after transfection, all groups were treated with different concentrations of $\mathrm{H}_{2} \mathrm{O}_{2}(0,400,600,800$ or $1000 \mu \mathrm{mol} / \mathrm{L})$ for 2 hours, and the HUVECs were then washed to remove the $\mathrm{H}_{2} \mathrm{O}_{2}$ prior to addition of 3-(4,5-dimethylthiazol-2-yl)-2,5-diphenyl tetrazolium bromide (MTT). 

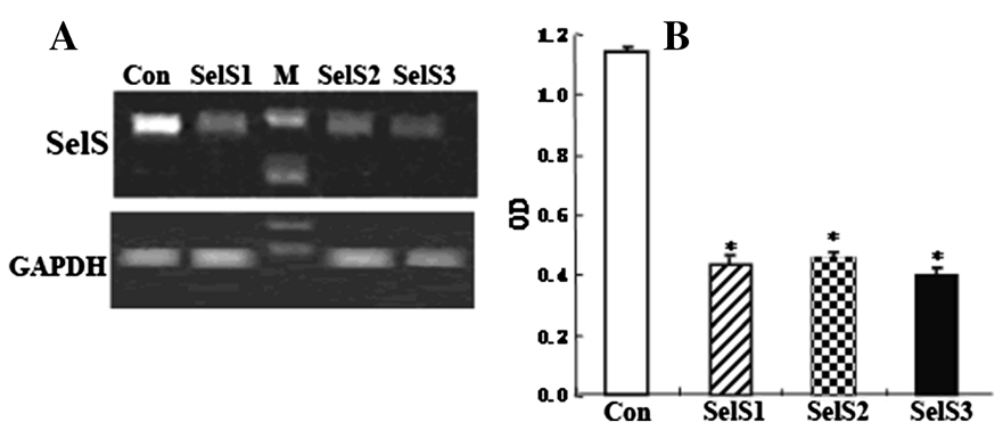

Figure 1 RT-PCR analysis of SelS gene expression after transfection of siRNA-SelS into HUVEC cells. A. RT-PCR analysis of SelS mRNA in cell lysates. B. The level of SelS mRNA expression presented as a ratio to GAPDH following densitometric analysis of the RT-PCR products. M: marker; Con: control group; SelS1, SelS2, SelS3: siRNA-SelS1, 2 and 3 plasmids, respectively. ${ }^{*} \mathrm{P}<0.01$ compared with the control group.

Then, the HUVECs were incubated with MTT $(0.5 \mathrm{mg} / \mathrm{mL})$ at $37^{\circ} \mathrm{C}$ for 4 hours. The solution was then removed and the formazan salts were dissolved with dimethyl sulphoxide, and the absorbance at $570 \mathrm{~nm}$ of the resulting solution was measured.

\section{Determination of MDA production and superoxide dismutase (SOD) activity}

The MDA level and SOD activity were analyzed using specific reagents according to the protocols provided by the manufacturer (Nanjing Jiancheng Bioengineering Institute, China). Briefly, thiobarbituric acid was used as substrate for the detection of MDA, and the xanthine oxidase method was used for the detection of SOD activity.

\section{Real-time PCR}

After treatment with $800 \mu \mathrm{mol} / \mathrm{L}_{2} \mathrm{O}_{2}$ for 24 hours, the cells in all groups were harvested and total RNAs were extracted using Trizol reagent (Invitrogen, USA). The levels of the mRNAs for Cav-1 and PKC $\alpha$ were examined by real-time PCR analysis. The sequences of the specific primers for Cav-1 and PKC $\alpha$ used for real-time PCR were as follows. Cav-1: sense primer, $5^{\prime}$-AACCTC CTCACAGTTTTCATCCA-3', antisense primer, 5'-GTC GTACACTTGCTTCTCGCTCA-3'; PKCa: sense primer, 5' -CCTTCAGACAAAGACCGACGACT-3', antisense primer, 5'-CTTCATCAGCTCCGAAACTCCAA-3'; GA PDH: sense primer, $5^{\prime}$-CGACACCCACTCCTCCACCT TTG-3', antisense primer, $5^{\prime}$-TCCACCACCCTGTTGC TGTAGCC-3'. The SYBR Green PCR Master Mix kit (Takara Biotechnology Co. Ltd.) was used according to the manufacturer's protocol. The real-time PCR reactions were performed using an Applied Biosystems 7500 Real-time PCR System (Life Technologies, USA). The PCR mix was first denatured at $95^{\circ} \mathrm{C}$ for 10 seconds, followed by 40 cycles of $95^{\circ} \mathrm{C}$ for $5 \mathrm{~s}, 59^{\circ} \mathrm{C}$ for 10 seconds and $72^{\circ} \mathrm{C}$ for 10 seconds. The data presented are from three independent experiments.

\section{Western blotting}

After treatment with $800 \mu \mathrm{mol} / \mathrm{L}_{2} \mathrm{O}_{2}$ for 24 hours, the cells in all groups were harvested and lysed for the extraction of total proteins. The protein content was determined using the Bradford assay. Briefly, $30 \mu \mathrm{g}$ protein samples were separated on sodium dodecyl sulfate polyacrylamide gels and transferred to polyvinylidene difluoride membranes (Millipore). A rabbit anti-human Cav-1 antibody (1:750, Santa Cruz, USA), a horseradish peroxidase (HRP)-labeled goat anti-rabbit secondary antibody (1:6000, Santa Cruz, USA), a mouse anti-human PKC antibody (1:200, Santa Cruz, USA) and a HRPlabeled goat anti-mouse secondary antibody (1:2000, Santa Cruz, USA) were used separately. The signals were detected using an enhanced chemiluminescence method (Hybond ECL, Amersham Bioscience, USA). The protein bands were recorded and analyzed using visionworksLS software (UVP Inc., USA). The expression levels of Cav-1 and PKC $\alpha$ protein were expressed as the density ratio divided by the density of $\beta$-actin.

\section{Statistical analyses}

Data are presented as mean \pm S.D. Statistical analyses were performed using a paired $t$-test and one-way analysis of variance followed by the LSD method with SPSS version 14.0 software. $P$ values of $<0.05$ were considered to be statistically significant.

\section{Results}

Construction of the SelS over-expression and interference plasmids

Construction of the SelS over-expression plasmid, pc-SelS

The amplified SelS cDNA sequence was identical to the sequence in Genebank (NM-018445). The eukaryotic expression plasmid, pc-SelS, was further verified by restriction endonuclease digestion and DNA sequencing. 
Construction and screening of the SelS interference plasmids The three siRNA-SelS plasmids were verified by sequencing. A plasmid to liposome ratio of 1:1.5 was chosen for liposome transfection.

Gene expression analysis showed that the expression of SelS was significantly inhibited in all three siRNASelS transfection groups $(\mathrm{P}<0.01)$, and siRNA-SelS1 was selected for the following experiment.

\section{Expression of siRNA-SelS and pc-SelS in HUVECS}

Real-time PCR analysis showed that SelS gene expression in both the pc-SelS over-expression group (82.51 \pm 0.42 , $\mathrm{P}<0.01$ versus vector control group) and the siRNA-SelS low expression group $(2.67 \pm 0.16, \mathrm{P}<0.01$ versus vector control group) was significantly different from the vector control group $(26.54 \pm 0.35)$. Additionally, expression of the SelS mRNA in the low expression group was knocked down by approximately 90\% (Figure 2A and B).

Western blot analysis showed similar results, and the expression of SelS protein in the siRNA-SelS group was decreased by approximately 30\% (Figure 2C).

\section{Effects of SelS on $\mathrm{H}_{2} \mathrm{O}_{2}$-induced EC injury Effects of SelS on cell viability}

All groups of HUVECs showed decreased cell viability after exposure to different concentrations of $\mathrm{H}_{2} \mathrm{O}_{2}$ for 6 hours. Cell viability in the siRNA-SelS group was significantly lower than that in the other groups $(\mathrm{P}<0.01)$, while cell viability in the SelS over-expression group was significantly higher than that in the other groups $(\mathrm{P}<0.01)$ following stimulation with $\mathrm{H}_{2} \mathrm{O}_{2}$ at concentrations of 800 and $1000 \mu \mathrm{mol} / \mathrm{L}$ (Figure 3A).

\section{Effects of SelS on MDA production}

The MDA content in the cell medium increased when the concentration of $\mathrm{H}_{2} \mathrm{O}_{2}$ was increased. The MDA content in the siRNA-SelS group was significantly higher than that in the SelS over-expression group, the normal control group and the vector transfection group (treated with $\mathrm{H}_{2} \mathrm{O}_{2}$ at concentrations of 600,800 and $1000 \mu \mathrm{mol} / \mathrm{L}$, respectively). The MDA content in the SelS over-expression group was significantly lower than in the other groups at these three concentrations of $\mathrm{H}_{2} \mathrm{O}_{2}$ (Figure 3B).

\section{Effects of SelS on SOD activity}

SOD activity in the siRNA-SelS group was significantly decreased, while SOD activity in the SelS overexpression group was significantly increased, by $\mathrm{H}_{2} \mathrm{O}_{2}$ treatment compared with the other groups $(\mathrm{P}<0.01)$ (Figure 3C).

\section{Effects of SelS on Cav-1 expression}

Cav-1 gene and protein expression were significantly increased by treatment with $800 \mu \mathrm{mol} / \mathrm{L} \mathrm{H}_{2} \mathrm{O}_{2}$ compared

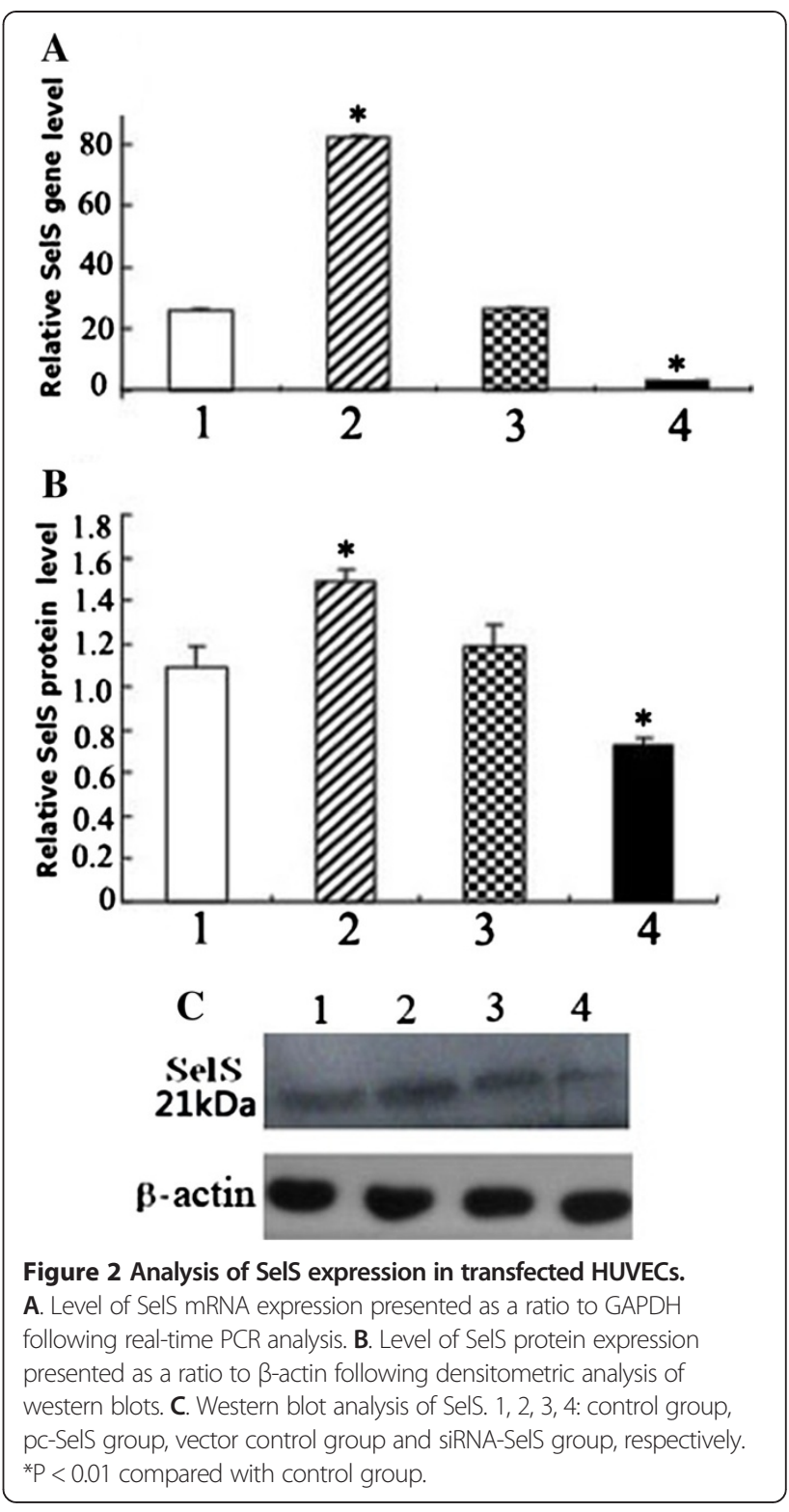

with the corresponding control groups not treated with $\mathrm{H}_{2} \mathrm{O}_{2}(\mathrm{P}<0.01)$. The levels of Cav-1 gene and protein were significantly decreased in the SelS over-expression group, and significantly increased in the siRNA-SelS group, when compared with the vector control groups after $\mathrm{H}_{2} \mathrm{O}_{2}$ treatment $(\mathrm{P}<0.01)$ (Figure 4$)$.

\section{Effects of SelS on PKCa expression}

$\mathrm{PKC} \alpha$ gene and protein expression were significantly increased in the siRNA-SelS group treated with $800 \mu \mathrm{mol} / \mathrm{L} \mathrm{H}_{2} \mathrm{O}_{2}$ compared with the corresponding groups treated with or without $\mathrm{H}_{2} \mathrm{O}_{2} \quad(\mathrm{P}<0.01)$. No significant changes were observed in the other groups $(\mathrm{P}>0.05)$ (Figure 5). 

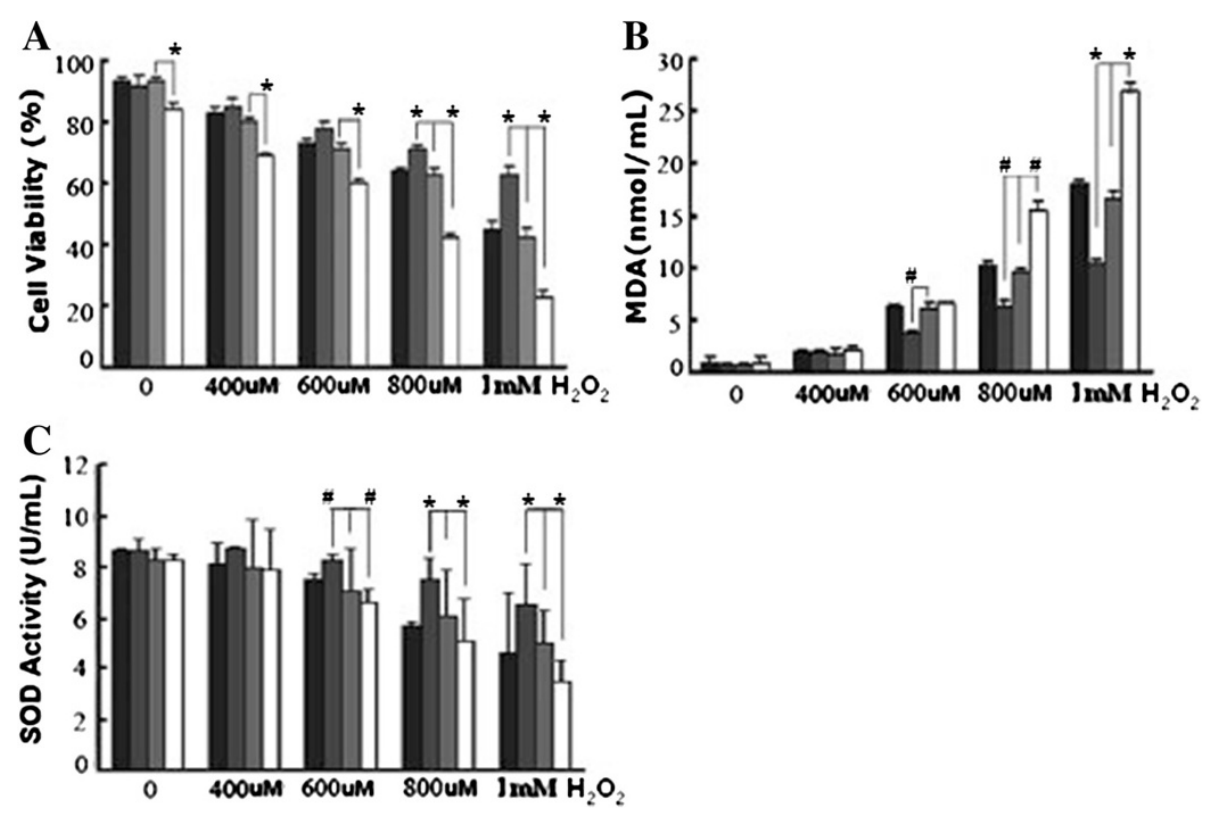

Figure 3 Effects of SelS on $\mathrm{H}_{2} \mathrm{O}_{2}$-induced EC injury. A. Effects of SelS on cell viability. B. Effects of SelS on MDA production. C. Effects of SelS on SOD activity. The black, dark grey, grey and white columns indicate the control group, pc-SelS group, vector control group and siRNA-SelS group, respectively. ${ }^{*} \mathrm{P}<0.05,{ }^{\#} \mathrm{P}<0.01$ compared with vector control group. $\mathrm{n}=3$.

\section{Discussion}

The novel selenoprotein, Tanis, was first identified in $P$. obesus, an animal model of type 2 diabetes and the metabolic syndrome. SelS, the human homolog of Tanis, was later found to be expressed in a variety of tissues as an important endoplasmic reticulum (ER) and plasma membrane-located selenoprotein.

SelS has been reported to have multiple biological activities. SelS promoted the reverse translocation of unfolded and misfolded proteins to the cytoplasm from the ER space for degradation after ubiquitination to maintain ER homeostasis [16]. Moreover, the SelS gene locates within a region of chromosome $15 q 26.3$, which also contains many inflammation-related loci. It was shown that proinflammatory cytokines activated the transcription of SelS, and upregulation of SelS inhibited the production of cytokines through a feedback loop [7,17]. SelS also protected Min6 islet cells from oxidative stress-induced toxicity [4]. However, the role of SelS in ECs has not yet been reported. Therefore, in the present study, the antioxidative effects of SelS in ECs were investigated using a gain/loss of function approach.

The results of the present study demonstrated that increased expression of SelS protected HUVECs from $\mathrm{H}_{2} \mathrm{O}_{2}$ damage by inducing increased cell viability and SOD activity, and decreased MDA production. Interfering with the SelS gene significantly decreased the antioxidative activity of HUVECs treated with $\mathrm{H}_{2} \mathrm{O}_{2}$, as shown by decreased cell viability and SOD activity, and increased MDA production. Our results are consistent with those of Zeng et al., who reported that interfering with SelS gene expression exacerbated LPS-induced inflammation injury in a liver cancer cell line [8]. Moreover, the present study demonstrated that expression of Cav-1 in ECs was increased by stimulation with $\mathrm{H}_{2} \mathrm{O}_{2}$, while the increase in Cav-1 in the SelS overexpression group was significantly lower than that in the SelS low expression group. These results suggest that the protective effect of SelS in response to $\mathrm{H}_{2} \mathrm{O}_{2}$-induced damage is related to the down-regulation of Cav-1.

Cav-1, the key structural protein in caveolae, is highly expressed in ECs. However, only a few studies on Cav-1 and ECs have been reported. In diabetic rats, oxidative stress in ECs increased the production of VEGF and then induced the gathering of caveolae and increased expression of Cav-1, leading to capillary hyperpermeability to plasma macromolecules and the intensification of membrane-cytoplasm transportation [18]. Later, the role of Cav-1 in the mechanism of oxidant-induced pulmonary vascular hyperpermeability and edema formation was investigated using a Cav-1(-/-) mouse. This study showed that $\mathrm{H}_{2} \mathrm{O}_{2}$ exposure induced the phosphorylation of Cav-1, which resulted in endothelial barrier disruption [19]. Further research also confirmed the induction of Cav-1 following oxidative stress and the fundamental role of Cav-1 in endothelial barrier function [20]. It also has been shown that caveolae and Cav-1 may play an important role in the mediation of native and modified LDL uptake/ efflux and transcytotic trafficking in ECs [21]. These findings suggest a pro-atherogenic role of Cav-1 and caveolae. Our present study has shown that SelS may down-regulate Cav-1 expression to protect ECs from oxidative stress, 

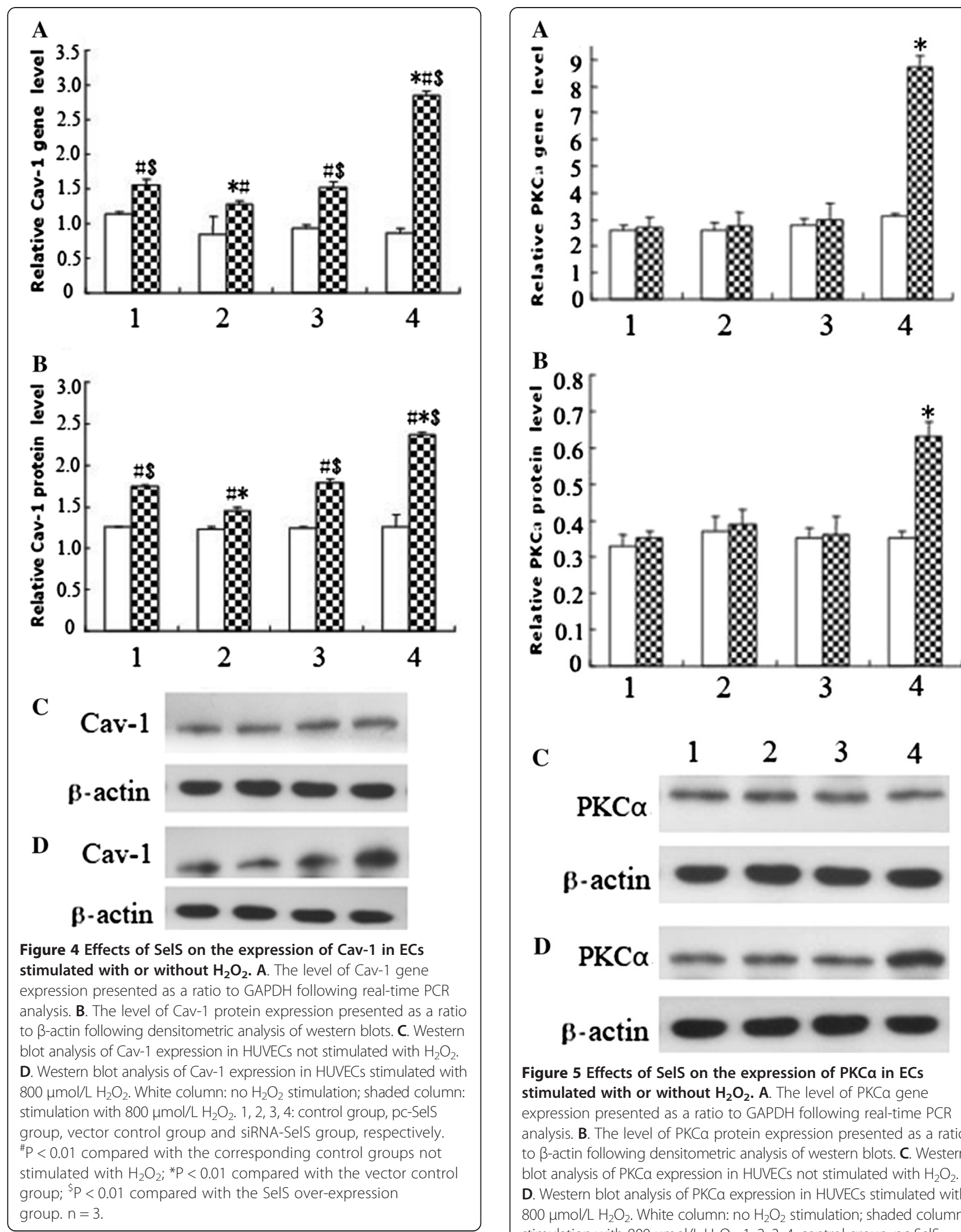

B
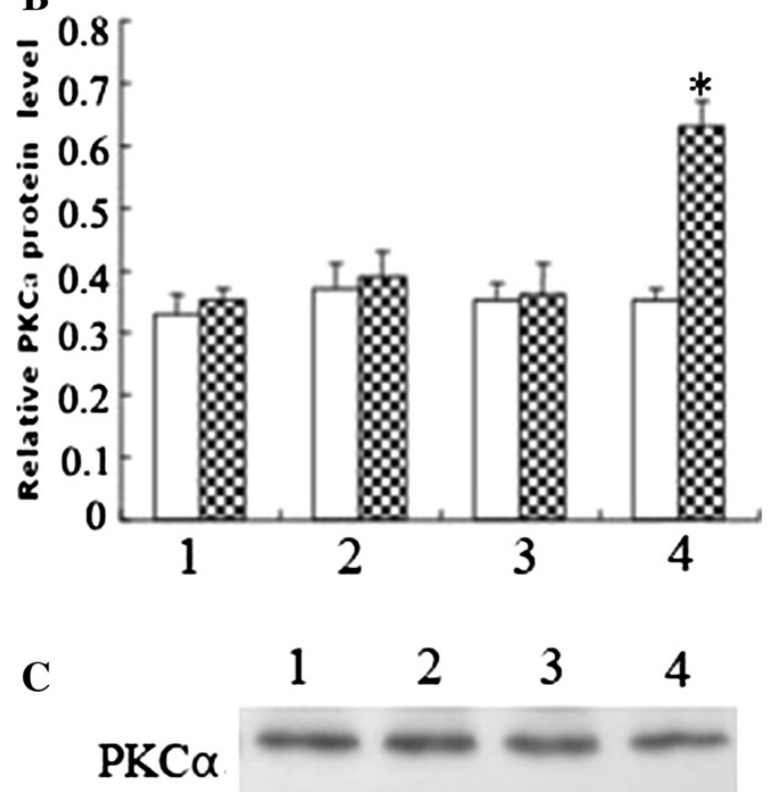

\section{B-actin}

\section{D $\mathrm{PKC} \alpha$}

\section{$\beta$-actin}

Figure 5 Effects of SelS on the expression of PKCa in ECs stimulated with or without $\mathrm{H}_{2} \mathrm{O}_{2}$. A. The level of PKCa gene expression presented as a ratio to GAPDH following real-time PCR analysis. B. The level of PKCa protein expression presented as a ratio to $\beta$-actin following densitometric analysis of western blots. $\mathbf{C}$. Western blot analysis of PKCa expression in HUVECs not stimulated with $\mathrm{H}_{2} \mathrm{O}_{2}$. D. Western blot analysis of PKCa expression in HUVECs stimulated with $800 \mu \mathrm{mol} / \mathrm{L} \mathrm{H}_{2} \mathrm{O}_{2}$. White column: no $\mathrm{H}_{2} \mathrm{O}_{2}$ stimulation; shaded column: stimulation with $800 \mu \mathrm{mol} / \mathrm{L} \mathrm{H}_{2} \mathrm{O}_{2}$. 1, 2, 3, 4: control group, pc-SelS group, vector control group and siRNA-SelS group, respectively. ${ }^{*} \mathrm{P}<0.01$ compared with the vector control group. $\mathrm{n}=3$. 
suggesting that SelS plays an inhibitory role during the early pathophysiologic stages of AS.

PKC has been reported to be involved in the mechanism of antioxidative stress. Numerous findings have revealed that PKC alpha is a mediator in the activation of stressresponse kinase. Kuo DY et al. demonstrated that PKC alpha knock-down could reverse the increase of SOD gene expression induced by phenylpropanolamine [22]. They revealed that PKC alpha signaling was an upstream mediator that regulates SOD gene expression, and the increase in SOD induced by PKC alpha can reduce oxidative stress. Makino J et al. showed that expression of SOD in the vascular wall was completely blocked by pre-treatment with GF109203X, an inhibitor of PKC, suggesting a direct effect of PKC on SOD expression [23]. Some seleniumcontaining compounds showed antioxidative effects by inhibiting $\mathrm{PKC}$ via redox-active cysteine residues in the catalytic domain of PKC [24,25]. Rayudu G and his team have shown that oxidative stress can stimulate PKC activity, and the interaction of seleno-compounds with the redoxactive cysteine-rich regions in PKC is important for their antioxidative function [25]. The present study showed that the expression levels of $\mathrm{PKC} \alpha$ gene and protein were significantly increased in the SelS low expression group, but there was no significant change in the SelS over-expression group. Therefore, SelS may have an inhibitory effect on PKCQ under normal conditions, while the decreased expression of SelS relieved the inhibition on PKC $\alpha$ leading to increased PKC $\alpha$ expression and oxidative injury. However, high expression of SelS showed no significant effect on the expression of PKC $\alpha$, suggesting that other mechanisms may be involved. Also, whether other subtypes of PKC (PKC $\beta, P K C \gamma)$ play roles in the SelS pathway should be investigated further.

\section{Conclusions}

Our study showed that up-regulation of SelS inhibited $\mathrm{H}_{2} \mathrm{O}_{2}$-induced Cav-1 expression, and down-regulation of SelS increased the expression of Cav-1 and PKC $\alpha$. Therefore, our study demonstrated, for the first time, the protective effect of SelS on oxidation-injured ECs. Furthermore, our results suggest that SelS may inhibit expression of Cav-1 to inhibit PKC $\alpha$ and block downstream activation of the PKC signaling pathway, leading to its antioxidative protection effect in ECs. Further experiments will focus on the mechanism in more detail. Specific inhibitors of Cav-1 and $\mathrm{PKC} \alpha$ will be used to demonstrate their roles in the SelS effect when SelS is over-expressed or knocked down. Also, co-precipitation of Cav-1 and SelS/PKC $\alpha$ will be performed. Moreover, SelS has been shown to perform complex biological activities via diverse mechanisms during many pathological processes, including oxidative stress, ER stress and cytokine production. Future studies will also focus on the link between the effects of SelS on oxidative stress, ER stress and inflammation. The in vivo effects of SelS transfection and knockdown in mice will also be investigated in order to clarify the role of SelS in the organism, which may be more meaningful for the prevention and therapy of AS-ECD.

\section{Competing interests}

The authors declare that they have no competing interests.

\section{Authors' contributions}

YZ, HL, QX, JJY and LLM designed and performed the experiments. JLD and $\mathrm{HL}$ interpreted the results and drafted the manuscript. CHS and HCZ analyzed the data. $\mathrm{RCH}$ contributed reagents and materials. All authors read and approved the final manuscript.

\section{Acknowledgments}

This work was supported by two grants from the National Natural Science Foundation of China (NSFC) (No. 30970841; No. 30670649).

\section{Author details}

'Department of Endocrinology, The First Affiliated Hospital of Dalian Medical University, Dalian 116011, Liaoning, China. ²Department of Pharmacology, College of Pharmacy, Dalian Medical University, Dalian 116044, Liaoning, China.

Received: 6 June 2013 Accepted: 30 October 2013

Published: 14 November 2013

\section{References}

1. Helton TJ, Bavry AA, Rajagopal V, Anderson RD, Yadav JS, Bhatt DL: The optimal treatment of carotid atherosclerosis: a 2008 update and literature review. Postgrad Med 2008, 120:103-112.

2. Hammes HP, Feng Y, Pfister F, Brownlee M: Diabetic retinopathy: targeting vasoregression. Diabetes 2011, 60:9-16.

3. Kryukov GV, Castellano S, Novoselov SV, Lobanov AV, Zehtab O, Guigó R, Gladyshev VN: Characterization of mammalian selenoproteomes. Science 2003, 300:1439-1443.

4. DW J, Kim TS, Chung YW, Lee BJ, Kim IY: Selenoprotein W is a glutathionedependent antioxidant in vivo. FEBS Lett 2002, 517:225-228.

5. Mostert V: Selenoprotein P: properties, functions, and regulation. Arch Biochem Biophys 2000, 376:433-438.

6. Zhang $\mathrm{S}$, Rocourt $\mathrm{C}$, Cheng $\mathrm{WH}$ : Selenoproteins and the aging brain. Mech Ageing Dev 2010, 131:253-260.

7. Walder K, Kantham L, McMillan JS, Trevaskis J, Kerr L, De Silva A, Sunderland T, Godde N, Gao Y, Bishara N, Windmill K, Tenne-Brown J, Augert G, Zimmet PZ, Collier GR: Tanis: a link between type 2 diabetes and inflammation? Diabetes 2002, 51:1859-1866.

8. Gao Y, Feng HC, Walder K, Bolton K, Sunderland T, Bishara N, Quick M, Kantham L, Collier GR: Regulation of the selenoprotein SelS by glucose deprivation and endoplasmic reticulum stress: SelS is a novel glucoseregulated protein. FEBS Lett 2004, 563:185-190.

9. Du JL, Sun CK, Lü B, Men LL, Yao JJ, An LJ, Song GR: Association of SelS mRNA expression in omental adipose tissue with Homa-IR and serum amyloid $A$ in patients with type 2 diabetes mellitus. Chin Med J (Engl) 2008, 121:1165-1168.

10. Karlsson HK, Tsuchida H, Lake S, Koistinen HA, Krook A: Relationship between serum amyloid a level and Tanis/SelS mRNA expression in skeletal muscle and adipose tissue from healthy and type 2 diabetic subjects. Diabetes 2004, 53:1424-1428.

11. Kelly E, Greene CM, Carroll TP, McElvaney NG, O'Neill SJ: Selenoprotein S/SEPS1 modifies endoplasmic reticulum stress in $Z$ variant alpha1antitrypsin deficiency. J Biol Chem 2009, 284:16891-16897.

12. Zeng J, Du S, Zhou J, Huang K: Role of SelS in lipopolysaccharide-induced inflammatory response in hepatoma HepG2 cells. Arch Biochem Biophys 2008, 478:1-6.

13. Frank PG, Woodman SE, Park DS, Lisanti MP: Caveolin, caveolae, and endothelial cell function. Arterioscler Thromb VasC Biol 2003, 23:1161-1168.

14. Fu C, He J, Li C, Shyy JY, Zhu Y: Cholesterol increases adhesion of monocytes to endothelium by moving adhesion molecules out of caveolae. Biochim Biophys Acta 1801, 2010:702-710. 
15. Lin D, Takemoto DJ: Oxidative activation of protein kinase Cgamma through the C1 domain effects on gap junctions. J Biol Chem 2005, 280:13682-13693.

16. Stoedter M, Renko K, Hög A, Schomburg L: Selenium controls the sex-specific immune response and selenoprotein expression during the acute-phase response in mice. Biochem J 2010, 429:43-51.

17. Zhang $Y$, Chen $X$ : Reducing selenoprotein $P$ expression suppresses adipocyte differentiation as a result of increased preadipocyte inflammation. Am J Physiol Endocrinol Metab 2011, 300:E77-E85.

18. Pascariu M, Bendayan M, Ghitescu L: Correlated endothelial caveolin overexpression and increased transcytosis in experimental diabetes. J Histochem Cytochem 2004, 52:65-76.

19. Sun Y, Hu G, Zhang X, Minshall RD: Phosphorylation of caveolin-1 regulates oxidant-induced pulmonary vascular permeability via paracellular and transcellular pathways. Circ Res 2009, 105(7):676-685.

20. Takeuchi K, Morizane Y, Kamami-Levy C, Suzuki J, Kayama M, Cai W, Miller JW: Vavvas DG: AMP-dependent kinase inhibits oxidative stress-induced caveolin-1 phosphorylation and endocytosis by suppressing the dissociation between c-Abl and Prdx1 proteins in endothelial cells. J Biol Chem 2013, 288(28):20581-20591.

21. Zhu Y, Liao HL, Wang N, Yuan Y, Ma KS, Verna L, Stemerman MB: Lipoprotein promotes Caveolin-1 and Ras translocation to Caveolae: role of cholesterol in endothelial signaling. Arterioscler Thromb Vasc Biol 2000, 20:2465-2470.

22. Kuo DY, Yang SF, Chu SC, Chen CH, Hsieh YS: Roles of protein kinase C alpha isozyme in the regulation of oxidative stress and neuropeptide $Y$ gene expression in phenylpropanolamine-mediated appetite suppression. J Neurochem 2009, 108(6):1495-1506.

23. Makino J, Kamiya T, Hara H, Adachi T: TPA induces the expression of EC-SOD in human monocytic THP-1 cells: involvement of PKC, MEK/ERK and NOX-derived ROS. Free Radic Res 2012, 46(5):637-644.

24. Gopalakrishna R, Gundimeda U, Chen ZH: Cancer-preventive selenocompounds induce a specific redox modification of cysteine-rich regions in $\mathrm{Ca}(2+)$-dependent isoenzymes of protein kinase $\mathrm{C}$. Arch Biochem Biophys 1997, 348:25-36.

25. Donovan J, Copeland PR: The efficiency of selenocysteine incorporation is regulated by translation initiation factors. J Mol Biol 2010, 400:659-664.

doi:10.1186/1479-5876-11-287

Cite this article as: Zhao et al:: Effects of selenoprotein $\mathrm{S}$ on oxidative injury in human endothelial cells. Journal of Translational Medicine 2013 11:287.

\section{Submit your next manuscript to BioMed Central and take full advantage of:}

- Convenient online submission

- Thorough peer review

- No space constraints or color figure charges

- Immediate publication on acceptance

- Inclusion in PubMed, CAS, Scopus and Google Scholar

- Research which is freely available for redistribution 